\title{
RATIONALES AND POSSIBILITIES OF WIDER DISSEMINATION OF FINANCIAL INSTRUMENTS IN THE CAP AND COHESION POLICY
}

\begin{abstract}
There are new challenges ahead for the EU: the refugee crisis, climate change, high youth unemployment, external security issues, cyber threats and terrorism. Therefore, financial resources will be needed. The EU budget after 2020 may be even more modest than the current one. As a consequence, competition for funding, particularly in the form of subsidies, will also be tightened, also under the CAP and cohesion policy. Financial instruments, namely repayable tools, should be more emphasized. The main aim of the article is to assess the potential use of financial instruments as tools that may partially replace the CAP and cohesion policy in the near future. Theoretical rationales (i.e. credit constraints, credit interventions) will be presented. An in-depth discussion will be undertaken (using elements of economics of public sector, public finance and political economy) on the perspectives of dissemination of these instruments. Our paper is a review study, with some elements of meta-analysis. The analysis shows that the aforesaid instruments can mainly be used for actions within rural, local and regional development programmes in which incomes may be generated, i.e. in investment, modernization and restructuring projects.
\end{abstract}

Keywords: financial instruments, subsidies, CAP, cohesion policy, EU budget.

JEL codes: Q14, Q18, H81. 


\section{Introduction}

On 1 March 2017, the so-called White Paper - the results of works of the European Commission, the European Parliament and the European Council was published. The White Paper offers five scenarios for the development of the EU by 2025 (European Commission, 2017a):

1. Carrying on;

2. Nothing but the Single Market;

3. Those who want more do more;

4. Doing less more efficiently;

5. Doing much more together.

Each of the scenarios is composed of three sections:

- General tendencies and volume (of the budget),

- Expenses (CAP; economic, social and territorial cohesion; new priorities; structural reforms related to the European Semester),

- Income of the EU Budget.

On 28 June 2017, the European Commission presented a reflection paper which is to launch a debate on the future budget of the EU (European Commission, 2017b). The reflection papers elaborated on the five scenarios above and contain the following information: articulation of policy priorities, expenses of the budget, competitiveness, the economic, social and territorial cohesion, agriculture, security, defence and migration, external actions, the fiscal capacity mechanism of the euro area and income. It is hardly surprising that expenses on the CAP and the cohesion policy are rising only in the "Doing much more together scenario. In the other scenarios, direct payments are limited solely to the group of farmers who are in a very difficult situation, and budget aid for all farms as regards risk management tools. The European Commission brings it up for a debate whether to re-nationalise at least a part of direct payments. As regards the future cohesion policy, aid for cross-border cooperation, social inclusion, employment and skills, innovation, climate change, energy and eco-efficient transformation are mentioned most often. In all the scenarios, we can see a clear emphasis on the need to increase the EU value added, as it will be very difficult without it to maintain the dominance of the CAP and the cohesion policy in the EU expenditure. It will not be easy as the report, which was prepared under the direction of Lamy and was published at the beginning of this year, shows that scientific research creates the highest value added. Consequently, the document proposes a twofold increase in the expenditure on science in the next budget at the expense of the traditional cohesion policy and CAP (European Commission, 2017b).

The above-mentioned reflection paper also contains item 4.2.2. entitled: "Financial instruments and the extended EU architecture". It is emphasised there that they constitute the source of flexibility of the EU finances, increased efficiency of budget expenditure and lower costs of implementation of fiscal tightening in the Member States. The effectiveness of their implementation requires 
clear and precise social and economic strategy, their skilful combination with subsidies (the so-called windows), integration with tools of similar nature in the Member States, and establishing a pan-European fund of funds. The instruments are suitable, in principle, only for projects and undertakings which generate income. This means that the list of their application is, in fact, very short, as it includes basic research, some infrastructural projects and investment in human capital. In practice, however, it is extended with the SME sector. On the other hand, institutional systems, necessary to deploy the above-mentioned financial instruments, should not be multiplied, as it generates considerable costs and inefficiencies, making them less transparent (European Commission, 2017b).

A growing interest in financial instruments under CAP results from a generally low effectiveness of application of subsidies. For example, a meta-analysis conducted by Minviell and Latruffe shows that in 1/4 of the research, a positive effect of subsidies on technical efficiency was achieved, and in more than half of the research, the relationship was negative, and no relationship of statistical importance was found in the remaining research (Minviell and Latruffe, 2016).

This year, Latruffe and co-authors carried out research in ten states of the former "EU15", where the impact of subsidies on the technical efficiency of farms specialised in milk production was assessed based on the FADN data from 1990-2007. It was found that (Latruffe, Bravo-Ureta, Carpentier, Desjeux and Moreira, 2017):

1. Relationships are clearly diverse when you examine coupled aid. In Belgium, the United Kingdom and in Italy, they were negative at an acceptable level of stochastic significance. In the other group of states (Denmark, France, Ireland and Germany), the analysed variables did not show any clear relationships in general. The correlation was positive and statistically significant only in Spain.

2. The transition to payments and, therefore, including the effecdecoupled ts of the so-called Luxembourg reform of 2003, results in definite loosening of their relationship with technical efficiency. In Belgium and Italy, they used to have a positive and statistically significant impact on the latter. A very small positive correlation also appeared in Germany and the United Kingdom, but only in the latter $\alpha=0.05$. In the other five states, the above payments led to deterioration of technical efficiency, but only in Spain and Portugal in a more distinct manner.

3. Apart from analysing the total impact of subsidies on technical efficiency, the impact of their individual types should also be examined. As regards decoupled aid which focuses on achievement of a few objectives, the search should be intensified so that it is adequately reflected in the product vector in the methodology and empirical models of assessment of technical efficiency and productivity, and their determinants. 
Using also the FADN database, Bokusheva presented her own analysis of the impact of subsidies on the total factor productivity (TFP) on plant farms in six EU Member States: the Czech Republic, France, Germany, Poland, Hungary and in the United Kingdom (Bokusheva, 2017). The following sub-periods were distinguished: 1995-2003 and 2004-2013. It turned out that there always was a negative correlation between the subsidies and TFP. The result was independent of the fact, whether the aid was expressed per 1 ha UAA or per farm in total. Again, it was confirmed that decoupled subsidies had less negative impact on productivity than coupled ones.

The authors of the article have used the FADN resources for various economic and financial analysis for years. Table 1 presents the fluctuations of selected indicators from the collection of farms run by individuals of the Polish FADN to provide a certain background for the possibility of a greater popularisation of financial instruments. It is also worth noting that self-funding of business dominates in the examined sample, as the equity-to-asset ratio drops only for big farms. In other words, debts, i.e. repayable instruments, are used only in the case of an adequate scale of business activity. The same relationship applied to the tied-up asset ratio whose lower values point to the higher flexibility of farms, and to the speed with which they adapt to the markets and their readiness to take restructuring actions. As a consequence, the growing economic value is translated into lower subsidy rates and higher profitability of assets and equity. However, equity has positive values only from small-medium farms upwards. This means that any potential programmes facilitating access to repayable instruments should have a clear bottom line. Otherwise, it will change into another channel for redistribution of public funds to agriculture and further weaken the motivation of the sector for structural transformation. In terms of the object, the focus of such programs should also be carefully thought over, as in Poland, only horticultural farms relatively heavily rely on debt now, as they are the least subsidised ones and, as general, are the most profitable ones. On the opposite side of the spectrum, however, we have herbivores, where profitability is low and the budgetary aid is one of the highest. To provide them with opportunities to use repayable instruments entails serious risk of low efficiency, or even waste. 
Table 1

The values of selected ratios in the farm panel from the sample of the Polish FADN depending on their economic value in 2015

\begin{tabular}{llcccccc}
\hline No. & \multicolumn{1}{c}{ Item } & $\begin{array}{c}\text { Unit of } \\
\text { measurement }\end{array}$ & $\begin{array}{c}\text { Very } \\
\text { small (A) }\end{array}$ & Small (B) & $\begin{array}{c}\text { Medium- } \\
\text {-small (C) }\end{array}$ & -large (D) & $\begin{array}{c}\text { Large } \\
(\mathrm{E} ; \mathrm{F})\end{array}$ \\
\hline 1 & Return on equity (1) & $\%$ & -5.1 & -1.1 & 2.1 & 4.2 & 6.1 \\
2 & Return on total assets (1) & $\%$ & -5.0 & -1.1 & 2.2 & 4.1 & 5.7 \\
3 & Equity-to-asset ratio & $\%$ & 99.6 & 98.2 & 95.5 & 91.6 & 85.9 \\
4 & Tied-up asset ratio & times & 13.2 & 9.6 & 8.9 & 9.2 & 8.4 \\
5 & Subsidisation rate I & $\%$ & 35.2 & 29.1 & 23.6 & 20.7 & 13.4 \\
6 & Subsidisation rate II (1) & $\%$ & 111.2 & 75.5 & 62.7 & 58.3 & 47.4
\end{tabular}

Explanatory note: Return on equity (1) = (income from a family farm - costs of own work) / average equity. Return on total assets (1) = (income from a family farm + interest - less costs of own work) / average equity. Equity-to-asset ratio $=$ equity at the end of the year / value of assets at the same moment. Tied-up $\underline{\text { assets ratio }}=$ fixed assets year end / current assets year end, achieved. Subsidisation rate I (payments for operations and investments, and compensation for milk) / plant + animal production). Rate II (1) (payments for operations and investments, and compensation for milk) / income from a family farm.

Source: own study.

The key objective of this article is to assess the possibility of using financial instruments as measures which can partially replace subsidies the CAP and the cohesion policy in the near future. The theoretical premises (i.e. credit constraints, credit interventionism) for using repayable instruments will be presented. The prospects of popularising the above-mentioned instruments will be discussed in length (with the use of the element of the theory of public sector economy, public finance and political economy). This study is a review study with some elements of meta-analysis. Apart from traditional methods of deduction and induction, a comparative presentation was also used.

\section{The essence and types of financial instruments (as compared to subsidies)}

Table 2 presents the most important approaches to the definition of "financial instruments". One should note that credit guarantees and sureties play a especially important role among the instruments listed. To some extent, they alleviate the negative consequences resulting from the imperfections/incompleteness of financial markets, which are very troublesome to the farmer, and contribute to the improvement of the creditworthiness (alleviation of the problem of negative selection and moral hazard). 
Table 2

Financial instruments (FI) - approaches to the definition and classifications

\begin{tabular}{ll}
\hline \multicolumn{1}{c}{ Item } & \multicolumn{1}{c}{ Scope of the definition, classification } \\
\hline $\begin{array}{l}\text { Polish balance sheet regulations } \\
\text { (Article 3.1.23 of the Accounting Act; }\end{array}$ & $\begin{array}{l}\text { FI are "contracts which cause financial assets to arise } \\
\text { for one of the parties thereto and financial obligations } \\
\text { or equity instruments for the other" }\end{array}$ \\
No. 121, item 591)
\end{tabular}

$\begin{array}{ll} & \text { Key financial engineering instruments (FEI) - } \\ & \text { repayable instruments: } \\ & \bullet \text { Loan } \\ & \text { - Surety } \\ & \bullet \text { Equity } \\ & \text { Other non-subsidy instruments: } \\ & - \text { Remission or repayment of a portion } \\ & \text { of the principal amount of a loan } \\ & \bullet \text { Remission or repayment } \\ \text { Cohesion Policy (Ecorys report 2016; } & \text { - Loan guarantees } \\ \text { EIPA-Ecorys-PwC, 2014; } & \text { Loans } \\ \text { European Commission, } & \text { Mezzanine } \\ \text { European Investment Bank, 2016). } & \text { Capital funds and venture capital } \\ & \text { Microcredit }\end{array}$

Explanatory note: a mezzanine - a hybrid form of financing, something in between sub-standard debt and equity. Mezzanine is not a collateral on business' assets. Owners of mezzanine funds participate in high-risk projects, expecting return of invested funds (the Mezzanine, 2017).

Source: own study on basis of the sources listed.

One should mention a couple of advantages of the use of financial instruments by borrowers - agricultural producers, and rural entrepreneurs:

Measurable benefits, which result from multiple transactions involving the funds, are generated, as we have the following effects here: the revolving effect, the leverage effect and equity multiplier ${ }^{1}$. These types of benefits are not present when traditional non-repayable instruments (subsidies) are made available.

The risk of overinvestment and overborrowing is decreased (from the perspective of a rural borrower), which translates into improved financial stability of the business.

In comparison with subsidies, financial instruments have some disadvantages, or their popularisation may be defined as at least problematic.

- The organisational model of the existing surety funds in Poland is imperfect (not very satisfying level of financial effectiveness). On the other hand, creation of an institutional system focused on agriculture and SME on rural areas entails high administrative and transaction costs for its potential beneficiaries.

\footnotetext{
${ }^{1}$ These categories will be discussed in detail in the following part of the paper.
} 
- Assessment of the investment with the use of financial effectiveness criteria (which have been used by our banks) puts applications for investment projects submitted by entities representing agriculture, small-scale agricultural and food processing or small-scare rural enterprise at a disadvantage.

It is very difficult to balance the above-mentioned advantages and disadvantages. It should be mentioned here that we deal with a certain kind of substitution between the instruments of of the $1^{\text {st }}$ and $2^{\text {nd }}$ pillar of CAP. There are also many complex and yet undefined interactions between the individual actions of the Rural Development Programme in regional and national programmes. Bankruptcy of a farm (in the economic meaning of the word and as a statutory term) and its social and legal consequences have very negative overtones in rural communities; however, the use of repayable instruments potentially entails such a risk. The social factors (which result from, among others the traditional, "patriarchal" model of succession on rural areas) may considerably decrease interest in instruments which do not constitute aid in the form of subsidies.

\section{Financial constraints and credit interventionism in agriculture}

Barry and Ellinger (2012) focused on the features which are decisive for the specific nature of financial processes in the agricultural sector. A straight majority of those characteristics also refer to countries in Central and Eastern Europe, which underwent political transformations (CEEC countries). These include, but are not limited to: (a) a significant share of rather small entities (considering the revenues from sales); (b) high capital intensity; (c) high demand of farms for investments in property (in building, structures, machines and devices); (d) agricultural production is based on repeated, long and biological production cycles; (e) heavy reliance of total agricultural income on generated non-agricultural income (problem of income diversification); (f) susceptibility of economic and production results from climatic and environmental factors; $(\mathrm{g})$ growing demand for technological innovations (including those related to precision farming, genetic improvements and biotechnological progress); (h) in the majority of cases, concentration of ownership rights and management (including risk management) in the person of the agricultural producer.

Figure 1 shows an algorithm for identification of different types of loan rationing, and, as a consequence, isolating household being at risk of having their access to credit limited. Zhao, Zhang and Barry (2014) propose identification, whether a household is in demand for third-party capital, as the first criterion. There can be a situation, where the household is contending with quantity rationing due to the fact that their application for a loan has been formally rejected by a financial institution (QR1), or their expectations were not satisfied with the external financing granted (QR2). Moreover, some entities give up trying to apply for a loan to avoid being burdened with transaction costs, e.g. costs connected with documenting collaterals (TCR1). Credit limitations may also be caused by 
too great physical distance from financial institutions, excessively bureaucratic procedures and too long waiting time to obtain a decision on granting a loan or credit (TCR2) and other reasons. Risk rationing can also be distinguished. It results from an excessive concern of managers about the repayment of debt by households. As a consequence, aversion to risk leads to a very moderate investment strategy (RR1). Moreover, contractual risk may discourage managers from getting credit funds (RR2). Further, a potential farmer-borrower may decide to leave the credit market, despite the fact that they have the necessary loan collaterals at their disposal (RR3).

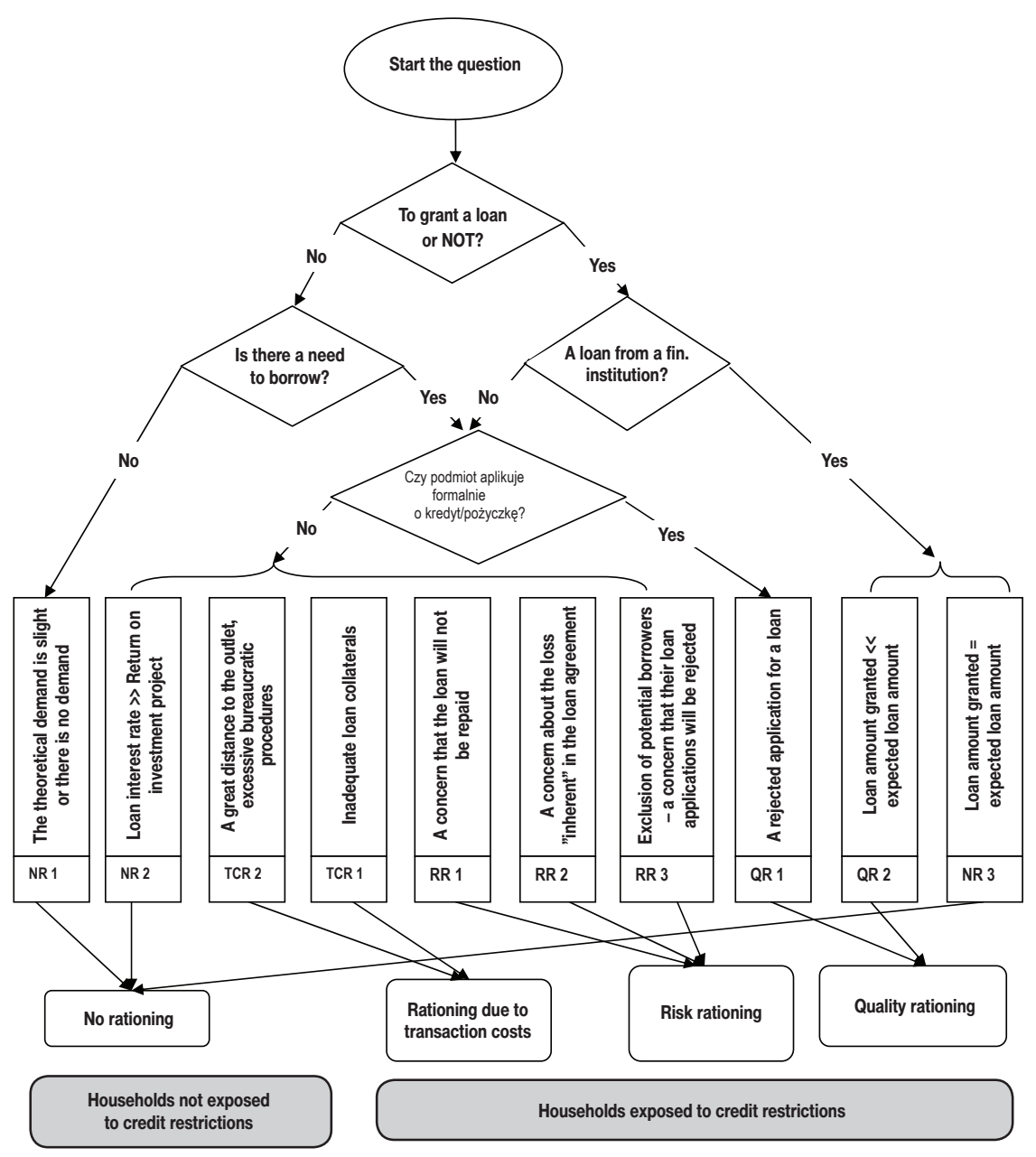

Fig. 1. Identification of households at risk of credit limitations.

Source: adaptation of the figure by: Zhao, Zhang and Barry (2014, p. 460). 
The results of two empirical studies are worth mentioning. The results of Verteramo Chiu, Khanthachavan and Turvey (2014) showed that, in both countries, risk rationing pertained to a lesser degree to farmers from farms with a higher value of assets. The flexibility of demand for credit was different depending on the segment separated according to the manner of rationing (risk rationed, price rationed vs quantity rationed). The research conducted by the above-mentioned team shows that actions aimed at increasing the accessibility of credit among farmers, and generally, inhabitants of rural areas, required understanding, now risk is perceived. Risk rationing is significant in terms of development of a market for loans for rural areas. Financial education for farmers is necessary to alleviate the negative effects of this type of rationing. Briggeman, Towe and Morehart (2007) demonstrated in their empirical research that farms and non-agricultural households, to which credit limitations apply, experienced lower production volume.

The conclusions of the research suggest a need to identify the attitudes of farmers, or rather residents of rural areas towards risk, mainly financial risk. It is significant as regards popularisation of any innovations introduced by financial institutions in the rural community.

The imperfections of the credit market result in slower process of capital accumulation, lower return on investment, as well as productivity of farms (Briggeman, Towe and Morehart, 2009). It is also significant that the negative effect of limited access to credit on the prosperity of those entities. At the micro level, credit limitations may have impact on decisions pertaining to allocation of resources. It has significant consequences form the perspective of expected effects of political decisions (Kropp, Turvey, Just, Kong and Pei, 2009). Private sector entities generally derive benefits (including increased investment activity) related to "loosening" of the above constraints. It should be emphasised that the implication of their existence is limited separation between decoupled payments and agricultural production. Political tools used for decreasing financial shortages in rural areas (also in agriculture) should highlight "pro-demand" interventions (i.e. stimulating demand for credit and loans) which mitigate the effects of risk faced by borrowers (Zawojska, 2008). When analysing the effects of credit interventionism in agriculture ${ }^{2}$, one should consider "mitigating negative consequences of credit rationing" which leads to evening out the supply of volume of loan funds (Kulawik, 1997). Moreover, by mitigating the risk of production activity, farmers are encouraged to increase the debt of farms, which leads to them being exposed to higher financial risk. As a consequence, there

\footnotetext{
${ }^{2}$ Among the credit intervention instruments in the Polish agriculture, the most popular are credit subsides (Kata, 2011). According to analyses of annual statements by the Agency for Restructuring and Modernisation of Agriculture, little interest was enjoyed by loan guarantees and sureties: in 1994-2014 the Agency granted a total of 202 loan guarantees and sureties for loan repayment to an amount of less than PLN 56 million (including 188 loan guarantees for the amount of PLN 52.3 million and 14 loan guarantees in the amount of PLN 3.7 million).
} 
is a higher probability that equity loss will occur and financial balance will be disturbed in agriculture (Kulawik, 1997).

The graphic model which shows the choice of an optimum level of financial leverage (Figure 2) in a farm is based on two assumptions:

- The hypothesis of the decreasing marginal return,

- Existing of external and internal rationing of capital.

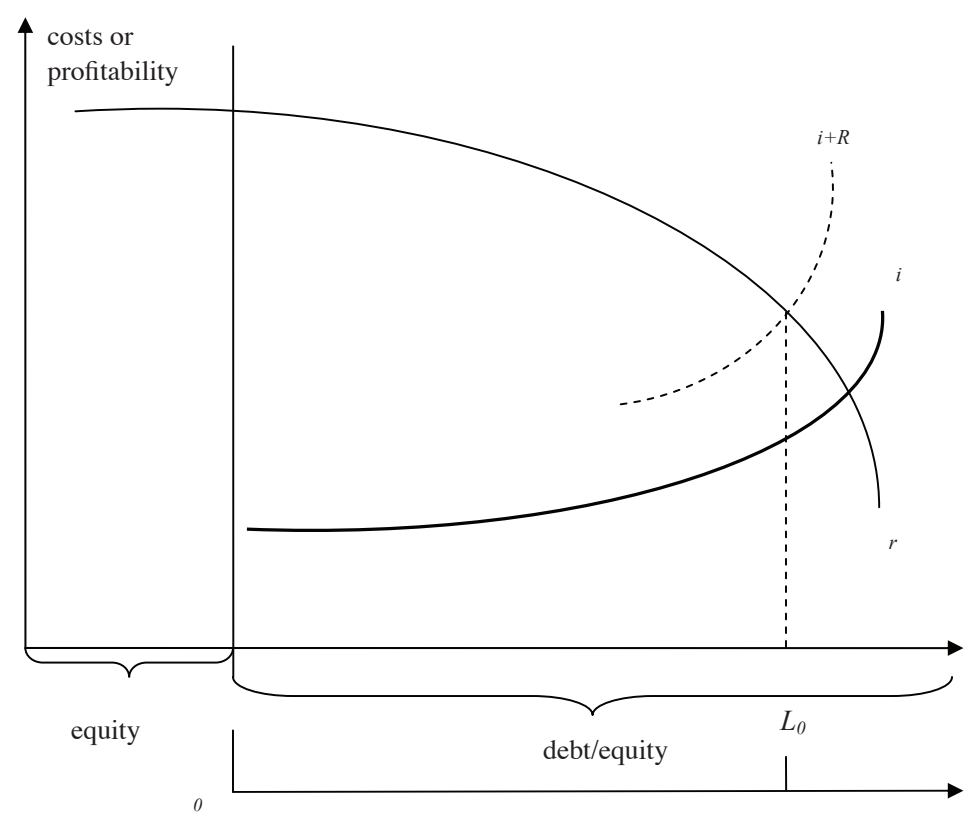

Fig. 2. The choice of an optimal level of financial leverage - farms.

Source: figure adaptation (Lee et al. 1988, as in: Kulawik 1997, p. 141).

Therefore, it will be justified to increase the level of financial leverage $(L)$ up to the point $(L O)$, where the marginal return on capital $(r)$ equals the marginal costs of third party capital $(i+R)$, with the sum of its interest rate $(i)$ and the socalled liquidity premiums. The last category has not been sufficiently clearly defined and measured yet, and it includes synthetically the total risk the farm, the the farmer's attitude towards risk, their ability to manage risk and the economic and organisational characteristics of the farm.

\section{Credit constraints of a farm - a model presentation}

As the basis for empirical verification of the credit constraint model, Ciaian, Fałkowski and Cancs (2012) used the approach from the model of Blancard, Boussemart, Briec and Kerstens (2006). The assumptions in the model presented by the above three researchers were the following (Ciaian, Fałkowski and Kancs, 2012): 
- A farm that maximises profits.

- Constant return to scale (CRS).

- Input credit constraint.

The profit function of a farm is expressed with the following formula (1):

$$
\Pi=p f(X, Y)-w_{X} X-w_{Y} Y
$$

where:

$p \quad$ - price of products,

$f(X, Y)$ - production function,

$w_{i} \quad-$ price of inputs,

$X \quad-$ constant input,

$Y \quad-$ variable input.

The inequality, is the most important element, in line with which for a farm characterised by credit constraints, the amount of loan obtained $(C)$ is not higher that the sum of expenses on inputs (2):

$$
\alpha w_{X} X+\delta w_{Y} Y \leq C
$$

where:

$\alpha, \delta$-artificial variables used for identifying the type of credit constraints, for example: $\alpha=1$ and $\delta=1$ - symmetrical credit constraints for both inputs.

A farm may be more burdened with credit debt in relation to only some inputs (in comparison with the other), which means that the credit constraint is asymmetrical. To make things simpler, we assume that the farm suffers a credit constraint in relation to inputs, $\mathrm{X}$ respectively, when $\alpha=1$ and $\delta=0$, and $Y$, when $\alpha=0$ and $\delta=1$.

A farm which maximises profit, being subject to a credit constraint in accordance with the equation below (3):

$$
\Psi=p f(X, Y)-w_{X} X-w_{Y} Y-\lambda\left(\alpha w_{X} X+\delta w_{Y} Y-C\right)
$$

where:

$\lambda$-Lagrange multiplier which pertains to the "hidden" price of the credit constraint.

The marginal value of products is greater than the price of inputs at the point of balance, where it is symetrically credit constrained: $\alpha=1, \delta=1$ and $\lambda>0$ and $p f_{X}>w_{X}, p f_{Y}>w_{Y}$. The farm could improve its economic result but the binding credit constraints make it difficult. The opposite situation is a situation of a asymmetrically credit constrained farm. Then the conditions are met: $\alpha=1, \delta=1 \mathrm{i} \lambda>0$, as well as $p f_{X}>w_{X}, p f_{Y}>w_{Y}$. 
In the opinion of the economists cited (Ciaian, Fałkowski and Kancs, 2012), credit constraints in agriculture may result from relatively long production cycles, especially for permanent crops and field crops. Agricultural producers must incur expenses to buy inputs and the revenues on sales are generated after the harvest (Ciaian and Swinnen, 2009). In addition, empirical studies, mainly those from the US (e.g. Benjamin and Phimister of 2002, Briggeman, Towe and Morehart of 2009), as well as from Europe (Petrick and Latruffe of 2003; Latruffe of 2005), Ciaian, Fałkowski and Kancs (2012) point to many determinants of farm's credit demand (e.g. value of equity, acreage, profitability, value of fixed assets, level of equity, subsidies granted and, in fact, subsidy rate).

\section{Value added of financial instruments}

Many methodological approaches may be applied to assets value added (VA) of financial instruments. In terms of practical usefulness (obligations related to reporting and ongoing financial monitoring) and transparency, the assessment/ determination of the following effects is the most important:

- Multiplier effect (ME - only in relation to loan guarantees);

- Leverage effect $) \mathrm{LE})^{3}$;

- Revolving effect (RE) (European Commission, European Investment Bank 2016).

The leverage effect of the EU funds, in accordance with the terminology adopted in the EU law, refers to the relation of funds, available to the end recipients, to the EU financial contribution:

$$
L E=(F F+S R+P R) / F F
$$

where:

$L E$ - leverage effect;

$F F$ - financial funds from the EU budget;

$S R$ - state resources, available to the end recipients;

$P R$ - public resources, available to the end recipients.

The algorithms for calculation of the leverage effect of financial instruments is shown in Table 3. At the same time, additional assumptions must be adopted (European Commission, European Investment Bank 2016, pp. 61-63):

- Contribution from the end beneficiary is not included,

- Face value of expenditure does not depend on its financial nature,

- Only the first investment cycle is included.

\footnotetext{
${ }^{3}$ The leverage effect in relation to business entities is defined as "raising or lowering the return on equity (ROE) as a result of the use of debt (foreign capital) as a source of financing business operations" (NBP, 2017).
} 
Algorithm for calculating the leverage effect of FI

Assessed leverage effect

total expected amount of finance to eligible final recipients
Algorithm (method)

(1) Contribution of EAFRD funds in the financial instrument

(2) Expected domestic co-financing (public and private)

(3) Expected contribution of other investors

(4) Interest and other profits, expected from management (treasury management)

MINUS

Management costs and charges related to the introduction of FI

\section{EAFRD funds committed to a given FI}

Explanatory note: EAFRD - European Agricultural Fund for Rural Development.

Source: European Commission, European Investment Bank (2016, p. 62).

The leverage effect depends on the type of instrument, the sector to which it is addressed, as well as the condition of the social and economic development of the country. Guarantees can usually generate the greatest leverage effect because not much of the capital is used. Moreover, the leverage effect can vary depending on the type of investment (for example, it is low for research and development) or the region (in rich regions, the private sector participates in investment projects more often) (World Bank, 2012).

The financial multiplier is defined as the relationship "between the amount of the programme contribution set aside to cover expected and unexpected losses from new loans or other risk-sharing instruments to be covered by the guarantees and the value of corresponding disbursed new loans or other risk-sharing instruments" (Commission Delegated Regulation (EU) No. 480/2014, Article 8 DA 480/2014). It is worth emphasising that the assessment/ calculation of the financial multiplier requires careful ex ante risk assessment for each type of loan guarantee offered. This entails inclusion of the market conditions, the investment strategy adopted for the instruments and, above all, the principles of the economy and efficiency.

The examples presented in Table 4 show that the capped amount is the product of total loan portfolio volume, the percentage of the amount of the guaranteed loan and the guaranteed cap rate. The amount and the expected costs related to management and administrative fees, which pertain to instruments constitutes the maximum amount of the liability of the Managing Authority for the loan guarantee (European Commission, European Investment Bank, 2016). 
Table 4

Determining the multiplier effect with different parameters of loan guarantees

\begin{tabular}{llrrr}
\hline Parameter & \multicolumn{1}{c}{ Item } & Example 1 & Example 2 & Example 3 \\
\hline 1 & Total portfolio volume & 1000 & 1000 & 1000 \\
2 & \% guarantee rate & $80 \% / 0.80$ & $80 \% / 0.80$ & $50 \% / 0.50$ \\
3 & Guarantee cap rate (\%) & $25 \% / 0.25$ & $10 \% / 0.10$ & $16 \% / 0.16$ \\
$4=1 \times 2 \times 3 *$ & Capped amount $(\%)$ & 200 & 80 & 80 \\
$5=1 / 4$ & Multiplier effect & 5 & 12.5 & 12.5
\end{tabular}

Explanatory note: the guaranteed amount is the product of the value of loans, the share of loans covered by the guarantee and the guaranteed raty (the last categories expressed as the decimal fraction).

Source: European Commission, European Investment Bank (2016, p. 52).

The specific feature of FIs, which distinguishes them from subsidy instruments, is the revolving effect (the possibility of using the funds by beneficiaries multiple times). The greater the effect, the greater the value added of FI. However, the value of the revolving effect depends on the number of factors (Table 5).

Table 5

Revolving effect in selected FIs

Instrument type Revolving effect mechanism

Visible in the cycle of commitment of liabilities and writing-off of guaranteed qualified expenses. After repayment of credit/loans, adequate funds

Loan of the programme will be released form the guarantee fund. The revolving effect guarantees of the guarantee depends on the risk taken by the guarantee fund. As repayment of loan capital under the guarantee must be ensured, the revolving effect may be lower than that for the loan fund.

For loan funds, the revolving effect starts when loans (or a part thereof) must Credit be repaid, and then subsequent loans are granted. Capital may be borrowed and loans multiple times. The volume of the revolving effect may be calculated as NPV of cash flow, including principal parts and interest. However, it depends on the length of the production cycle.

Source: own study based on: European Commission, European Investment Bank (2016, p. 53).

Financial instruments (FI) also have the so-called qualitative value added. It results from their multi-channel effect on the entities in the agricultural sector and its surroundings. It is about the following issues (Loriz-Hoffmann, 2012; European Commission, European Investment Bank, 2016, pp. 54-55):

- They minimise distortions on the credit market;

- They usually include an innovative offer, e.g. microcredit; 
- They stimulate the potential of some entities with low creditworthiness, e.g. groups of producers, clusters, partnerships (European Innovation Partnerships, EIP);

- Young farmers have better opportunities for development who are, to some extent, "excluded" by the traditional segments of the credit market;

- In some segments of agricultural and food production (e.g. selected permanent crops, wine production), there might be very long return periods, which makes it much more difficult to obtain third party capital from a financial institution;

- Issue of FI contributes to reduce market imperfections which are typical not only for the region but also for the agricultural sector;

- In addition, attracting new source of knowledge and know-how;

- Supporting building of potential and promotion of "business mentality", i.e. using funds for project with value added, profitable and very financially sustainable.

\section{Prospects for popularisation of financial instruments}

The EU is evidently regaining its pre-crisis macroeconomic condition, and partly also the fiscal condition, which is particularly visible in budget deficits. However, the public debt in relation to GDP continues to be high. A considerable part of the Community members have the opportunity to incur debts very cheaply, of which the most spectacular expression is the negative interest rate of some types of treasury bonds. Nevertheless, there are few reasons to believe that net payers will agree to bear the additional burden to finance community policies. The task to replenish the shortage of about EUR 10-13 billion annually, resulting from Brexit, is now a challenge. The shortage may increase, if a separate budget is implemented for the euro area, as e.g. in the oft-quoted French proposal, where it constitutes as much as $10 \%$ of the EU budget. It could mean a loss of as much as EUR 100 billion in the entire perspective. Depending on the results of elections in Germany, there is some probability that the scenario of transformation of the euro area into a "transfer union" will come true. It would mean a definite deterioration of the position of the Member States from our part of Europe. The fiscal tension in the EU will undoubtedly increase as a result of US expectations that European signatories of NATO will spend at least $2 \%$ of their budgets on defence annually. Amounts of about EUR 70 billion per annum are given. This proportion will continue to grow, when the Community wants to implement its own defence policy, which is complementary to NATO. There are other challenges which have already been mentioned in the introduction. Therefore, it must be assumed that there will be less money in the new EU budget (2020) than in the present one.

European banks are also gradually rebuilding their pre-crisis economic and financial condition, but it proceeds slowly and under constant supervision of 
the EU and national institutions which were especially created for that purpose. The purpose of the new community regulations of November 2016 is to further strengthen banks in terms of capital and to better manage bank risk. This must translate into their lower profitability, additionally decreased by the non-standard policy of the European Central Bank but, on the other hand, it is to protect European taxpayers against another bailout of banks with budget funds. The return of inflation and the EBC forecast that it will probably return to standard monetary policy by 2018 , should encourage banks to increase lending, provided that there is greater interest of businesses and households in new loans. A positive fact in the recent EU regulation is the implementation of the proportionality principles, and therefore, the differentiation depending on the size of banks, the scope of operations and their complexity, and risk exposure. Therefore, it should be easier to provide commercial credit to small and medium enterprises, to which financial instruments are addressed. As one can see, there are relationships of complementarity and competitiveness between the last two. The phenomenon is also present in the Polish banking system. In general, it is perceived as a well-capitalised sector, but it can completely change when, e.g. the problem of foreign currency loans remains unsolved. Under our conditions, there is also the issue of the so-called banking tax. Its construction discourages banks from providing long-term loans to companies, but promotes short-term consumer loans and financing the state budget. This example shows that our legislators should carefully consider the complexity of interdependencies in modern economies each and every time. Possible, somewhat artificial creation of demand for financial instruments may not be considered to be a rational course of action in this context.

On 18 February, the European Commission presented Green Paper - Building a Capital Markets Union, which is abbreviated to "Capital Markets Union", CMU in short (European Commission, 2015). This document about deepening and extending financial integration in the Community as of 2019. A more extensive presentation pertains to achievement of the following detailed objectives:

- To provide direct capital flow from investors to enterprises, especially small and medium enterprises (SME);

- To stimulate inflow of capital from outside of the EU;

- To increase stability of the entire EU financial system by e.g. its further diversification;

- To increase the effectiveness of capital markets, which should translate into the drop in costs of obtaining funds.

Anticipating the publication of the above document of the European Commission, its President - Jean-Claude Juncker - as early as on 1 November 2014, announced the European Fund for Strategic Investments, (EFSI), ever since called the "Juncker Plan" (European Commission, 2014). The implementation of the plan was to ensure growth of investment and, consequently, economic 
recovery and improved competitiveness of the EU economy. In November 2014, the European Commission presented its announcement thereon (document $\operatorname{COM}(2014) 903)$. The investment plan is based on three key elements: to mobilise funds for investment, to aid real economy with financial funds and to improve the investment environment (Figure 3).

European Fund for Strategic Investments (EFSI) is the main tool for implementing the investment plan. It is used to support projects which are strategic for the EU, especially infrastructural projects. However, it should also be used to support SME and companies with average capitalisation. The fund was created together by the European Commission and the European Investment Bank (EBI). The estimated multiplier effect was to amount to 15, i.e. the commitment by the European Commission of EUR 16 billion and EUR 5 billion by EBI was to generate EUR 315 billion in the form of investment in the economy. The rules of operation of EFIS are laid down in the (EU) Regulation 2015/1017 (European Commission, 2015).

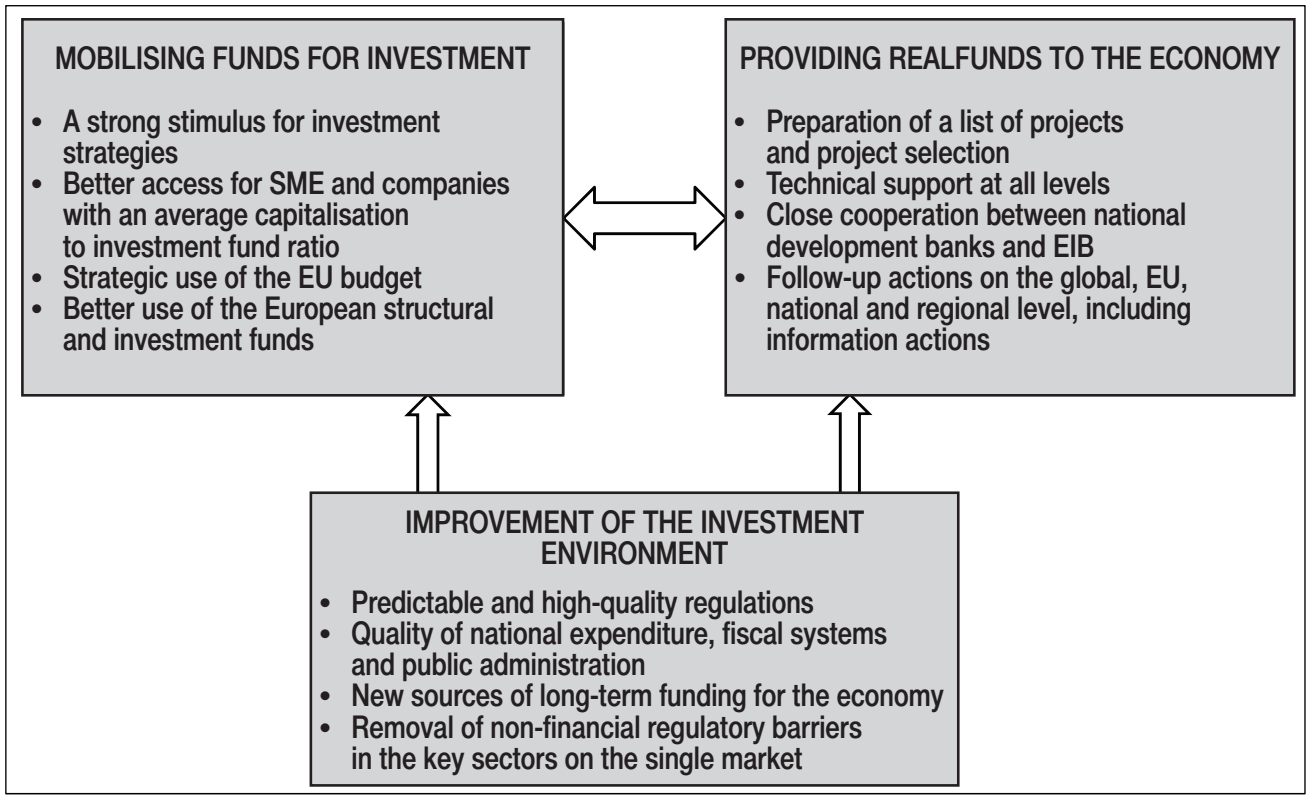

Fig. 3. Three key elements of the investment plan for Europe.

Source: European Commission (2014).

The operationalisation of the "Juncker Plan" entails the use of financial engineering, where from the initial capital of EUR 21 billion (16 billion in guarantees from the EU budget and only 5 billion of "real cash" from the European Investment Bank) will generate EUR 315 billion of funds for infrastructural projects 
and aid for big enterprises and the SME sector by 2019 (as part of the European Investment Fund). The interest in EFSI is so great that the European Commission prepared its extension in December 2016, in the form of the "Juncker Plan 2.0 ", up to the lending capacity of EUR 500 billion by 2020. In the context of works on the next EU budget, the opinion that "Juncker Plan 3.0" could significantly reduce the amount of offered subsidies is being more and more often expressed. One cannot forget here that the subsequent "Juncker Plans" do not use the division into national envelopes, which undoubtedly result in the deterioration of the position of states and companies from our part of Europe as regards application for loans. For the time being, Poland uses the EFSI funds best among the countries of the so-called New Union. The works related to the Capital Markets Union (CMU) are also continued so that the savings of Europeans will be more actively committed to business activity. A new instrument - Pan-European Venture Capital Fund of Funds was established; regulations on the securitisation of assets have been made more flexible and there is a search for a formula to use the potential of the so-called fintech - technological companies which operate in the financial sector.

\section{Conclusions}

The two scenarios of the Community development by 2025 proposed by the EU institutions, i.e. "Nothing but the Single Market", and particularly "Doing less more efficiently" will pose a serious challenge to the future financing of the two policies, i.e. CAP and Cohesion Policy, whose share in the current financial framework make up nearly $70 \%$ of expenses. After 2020 , there were will be much less funds according to the above scenarios, and consequently, the competition for them will be tougher. In the other three scenarios, the need for a greater focus on European value added and increased efficiency in granting subsidies will be also brought up. This should naturally increase the interest in broader use of financial instruments in the future and obtaining funds for them with financial engineering and public-private partnership. In the first place, such instruments should be made available as part of the cohesion policy, which may potentially generate greater value added than CAP but does not have the same political support as the latter. The Polish government starts to see those interdependencies. Consequently, the Ministry of Development, which is responsible for the cohesion policy in Poland, foresees that financial instruments will make up $7 \%$ of the policy's budget by 2020 , and that share will rise to $30 \%$ in 2030 . However, one should remember that these instruments do not have a separate national envelope at the EU level, but, on the other hand, they are not made available as part of competitions.

As regards CAP, however, a strong growth of significance of financial instruments cannot be expected in the future. It results mainly from the fact that it is dominated by the first pillar, and by direct payments therein. Now that pillar eats 
up 70-80\% of expenditure on agriculture in the Member States. Any attempts at reducing direct payments will certainly meet with strong opposition of agricultural circles which still have a strong political position. Of course, an increase in the share of repayable instruments in the second pillar should be considered, if there are enough enterprises which generate sufficient income to serve them. In Poland, we will find them mainly on bigger farms, but even there, only in some fields of production and areas of non-agricultural activity. However, the instruments should be integrated with the concessionary loans, bridge loans and commercial loans which are already available, each and every time. 


\section{References}

Accounting Act (Journal of Laws of 1994, no. 121, item 591).

Barry, P., Ellinger, P. (2012). Financial Management in Agriculture. $7^{\text {th }}$ Edition, Pearson Prentice Hall, Upper Saddle River.

Benjamin, C., Phimister, E. (2002). Does Capital Market Structure Affect Farm Investment? Comparison Using French and British Farm-Level Panel Data. American Journal of Agricultural Economics, .no. 84, pp. 1115-1129.

BGK (2012). Zarządzanie instrumentami pozadotacyjnymi UE - doświadczenia BGK (online presentation) Łódź, 24.05.2012. Retrieved from: https://www.mos.gov.pl/g2/big/2012_06/313bfcbd60caef8281fb41b94b5cf35e.ppt (access date: 10.05.2017).

Blancard, S., Boussemart, J.P., Briec, W., Kerstens, K. (2006). Short- and Long-Run Credit Constraints in French Agriculture: A Directional Distance Function Framework Using Expenditure-Constrained Profit Functions. American Journal of Agricultural Economics no. 88(2), pp. 351-364.

Bokusheva, R. (2017). Evaluating dynamics, sources and drivers of productivity growth at the farm level. Paris: OECD.

Briggeman, B.C., Towe, Ch., Morehart, M. (2007). Credit Access: Implications for Sole-Proprietor Household Production. Proceedings from Agricultural Economics Association Annual Meeting, Portland, OR, July 29-August, no. 1.

Briggeman, B.C., Towe, Ch.A., Morehart, M.J. (2009). Credit Constraints: Their Existence, Determinants, And Implications For U.S. Farm And Nonfarm Sole Proprietorships. American Journal of Agricultural Economics, no. 91(1) (February 2009), pp. 275-289.

Ciaian, P., Fałkowski, J., Kancs, d'A. (2012). Access to credit, factor allocation and farm productivity. Evidence from the CEE transition economies. Agricultural Finance Review, vol. 72, no. 1, s. 22-47.

Ciaian, P., Swinnen, J.F.M. (2009). Credit Market Imperfections and the Distribution of Policy Rents. American Journal of Agricultural Economics, no. 91(4), s. 1124-1139.

Commission Delegated Regulation (EU) No 480/2014, Article 8 DA 480/2014.

Commission Delegated Regulation (EU) 2015/1558 of 22 July 2015 supplementing Regulation (EU) 2015/1017 of the European Parliament and of the Council by the establishment of a scoreboard of indicators for the application of the EU guarantee, (OJ L 244).

Ecorys (2016). Ocena ex ante celowości zastosowania instrumentów finansowych w ramach Programu Rozwoju Obszarów Wiejskich na lata 2014-2020. Raport dla MRiRW. Warsaw, 30.11.2016. Retrieved from: http://www.minrol.gov.pl/Ministerstwo/BiuroPrasowe/Informacje-Prasowe/Ocena-ex-ante-celowosci-zastosowania-instrumentowfinanso-wych-w-ramach-PROW-2014-2020 (10.05.2017).

EIPA-Ecorys-PwC (2014). Financial instruments in Cohesion Policy, 2014-2020: Ex-ante assessments. Managing Authority training, June 2014 (for European Commission and European Investment Bank). Retrieved from: http://ec.europa.eu/regional_policy/sources/thefunds/fin_inst/pdf/ex_ante_training.pdf (access date: 10.05.2017).

European Commission (2014). The European Fund for Strategic Investments, EFSI. Brussels, 01.11.2014. 
European Commission (2015). Green Paper. Building a Capital Markets Union, 18.11.2015. Retrieved from: http://ec.europa.eu/finance/consultations/2015/capital-markets-union/ docs/green-paper_en.pdf.

European Commission (2016). European Structural and Investment FUNDS and European Fund for Strategic Investments complementarities Ensuring Coordination, Synergies and Complementarity February 2016. Retrieved from: http://ec.europa.eu/regional_policy/sources/thefunds/fin_inst/pdf/efsi_esif_compl_en.pdf

European Commission (2017a). White Paper on the Future of Europe. Reflections and scenarios for the EU27 by 2025. Brussels, 1.03.2017. Retrieved from: https://ec.europa.eu/ commission/sites/beta-political/files/white_paper_on_the_future_of_europe_en.pdf

European Commission (2017b). Reflection Paper on the Future of EU Finances. Brussels, 28.06.2017. Retrieved from: https:/ec.europa.eu/commission/sites/beta-political/files/ reflection-paper-eu-finances_en.pdf

European Commission, European Investment Bank (2016). Methodological handbook for implementing an ex-ante assessment of agriculture financial instruments under the EAFRD. EIB, Advisory Services, fi-compass, Luxembourg.

Kata, R. (2011). Interwencjonizm kredytowy w rolnictwie a problem dostępu rolników do kredytu bankowego. Roczniki Nauk Rolniczych, SERIA G, vol. 98, issue 2, pp. 116-126.

European Commission (2009). Economic Crisis in Europe: Causes, Consequences and Responses. European Economy, no. 7/209.

European Commission (2014a). Communication from the European Comission to the European Parliament, the Council, the European Central Bank, the European Economic and Social Committe, the Committee of the Regions and the European Investment Bank. COM(2014)903.

European Commission (2014b). Polityka spójności 2014-2020. Retrieved from: http://ec.europa.eu/regional_policy/what/future/index_pl.cfm (access date: 7.10.2014).

European Commission (2014c). Cohesion Policy 2014-2020. Retrieved from: http://ec.europa.eu/regional_policy/what/future/index_pl.cfm (7.10.2014).

European Commission (2015). The Investment Plan for Europe - Questions and Answers. Brussels, 20 July 2015. Retrieved from: http://europa.eu/rapid/press-release_MEMO15-5419_pl.pdf

Kropp, J.D., Turvey, C.G., Just, D.R., Kong R. Pei G. (2009). Are the poor really more trustworthy? A micro-lending experiment. Agricultural Finance Review, vol. 69, issue 1, pp. 67-87.

Kulawik, J. (1997). Rozwój finansowy a wzrost i rozwój ekonomiczny w rolnictwie. Studia i Monografie, no. 83. Warsaw: IERiGŻ.

Kulawik, J. (2000). Makro- i mikroekonomiczne przesłanki oraz skutki interwencjonizmu państwowego w sferze kredytowania rolnictwa. Synteza. Warsaw: IERiGŻ.

Latruffe, L., Bravo-Ureta, E.B., Carpentier, A., Desjeux, Y., Moreira, H.V. (2017), Subsidies and Technical Efficiency in Agriculture: Evidence from European Dairy Farms. American Journal of Agricultural Economics, vol. 99, no. 3 pp. 783-799.

Loriz-Hoffmann, J., (2012). Financial instruments in rural development 2014-2020: programming and policy elements. Retrieved from: http://enrd.ec.europa.eu/enrd-static/ fms/pdf/B13F3718-F988-2D49-B2C6-C291DA8F0DE6.pdf 
Mezzanine. Retrieved from: http://www.mezzanine.com.pl/ABC/cotojest.html.

Minviell, J.J., Latruffe, L. (July 2016). Effects of Public Subsidies in Farm Technical Efficiency: A Meta-Analysis of Empirical Results. Applied Economics, vol. 49, issue 2, pp. 213-226.

NBP (2017). Portal edukacji ekonomicznej. Efekt dźwigni finansowej. Retrieved from: https://www.nbportal.pl/slownik/pozycje-slownika/efekt-dzwigni-finansowej.

Petrick, M. Kloss, M. (2012). Drivers of agricultural capital productivity in selected EU member states. Factor Markets. Working Paper, no. 30, September.

Regulation (EU) 2015/1017 of the European Parliament and of the Council of 25 June 2015 on the European Fund for Strategic Investments, the European Investment Advisory Hub and the European Investment Project Portal and amending Regulations (EU) No 1291/2013 and (EU) No 1316/2013 - the European Fund for Strategic Investments (OJ L 169).

Verteramo Chiu, L.J., Khantachavana, S.V., Turvey, C.G., (2014), Risk rationing and the demand for agricultural credit: a comparative investigation of Mexico and China. Agricultural Finance Review, vol. 74, issue 2, pp. 248-270.

Vienna Initiative Working Group on Credit Guarantee Schemes (2014). Credit Guarantee Schemes for SME lending in Central, Eastern and South-Eastern Europe.

World Bank (2012). World Bank Guarantee Program for the Consultation of Modernizing the World Bank's Operational Policy on Guarantees. January 2012. Retrieved from: http://siteresources.worldbank.org/INTGUARANTEES/Resources/HighlightsWBG ProgramforConsulJan252012.pdf

Zawojska, A. (2008). Uwarunkowania i kanały finansowania rolnictwa w Polsce. Zeszyty Naukowe SGGW w Warszawie, Ekonomika i Organizacja Gospodarki Żywnościowej, no. 65 , pp. 95-108.

Zhao, J. Zhang, J., Barry, P.J. (2014). Do formal credit constraints affect the rural household consumption in China?, Agric. Econ. - Czech, no. 60(10), pp. 458-468. 


\author{
JACEK KULAWIK \\ MICHAE SOLIWODA \\ BARBARA WIELICZKO \\ Instytut Ekonomiki Rolnictwa i Gospodarki Żywnościowej \\ - Państwowy Instytut Badawczy \\ Warszawa
}

\title{
PRZESŁANKI I MOŻLIWOŚCI SZERSZEGO STOSOWANIA INSTRUMENTÓW FINANSOWYCH W WPR I POLITYCE SPÓJNOŚCI
}

\begin{abstract}
Abstrakt
Przed Unia stoi szereg nowych wyzwań: kryzys uchodźczy, zmiana klimatu, wysokie bezrobocie wśród młodzieży, kwestie bezpieczeństwa zewnetrznego, cyberzagrożenia i terroryzm. Unijny budżet po 2020 roku może być nawet skromniejszy niż obecny. W konsekwencji zaostrzy się konkurencja o fundusze, szczególnie o charakterze dotacji, również $w$ ramach WPR i polityki spójności. Na znaczeniu powinny zatem zyskiwać instrumenty finansowe, a więc źródła zwrotne. Podstawowym celem artykułu jest ocena możliwości wykorzystania instrumentów finansowych jako środków, które $w$ niedalekiej perspektywie moga cześsciowo zastapić dotacje $w$ WPR i polityce spójności. Przedstawione zostana przesłanki teoretyczne (tj. ograniczenia kredytowe, interwencjonizm kredytowy) stosowania instrumentów zwrotnych. Podjęta zostanie pogłębiona dyskusja (z wykorzystaniem elementów teorii ekonomii sektora publicznego, finansów publicznych i ekonomii politycznej) nad perspektywami upowszechnienia ww. instrumentów. Opracowanie ma charakter studium przegladowego, z pewnymi elementami metaanalizy. Z dokonanej analizy wynika, że instrumenty te moga znaléć głównie zastosowanie $w$ działaniach $w$ ramach programów rozwoju wiejskiego, lokalnego i regionalnego, w których może być generowany dochód, a więc $w$ przedsięwzieciach o charakterze inwestycyjnym, modernizacyjnym i restrukturyzacyjnym.
\end{abstract}

Słowa kluczowe: instrumenty finansowe, dotacje, WPR, polityka spójności, budżet UE.

Accepted for print: 15.12.2017.

Unless stated otherwise all the materials on the website are available under the Creative Commons Attribution 3.0 Poland license. Some rights reserved to the Institute of Agricultural and Food Economics - National Research Institute.

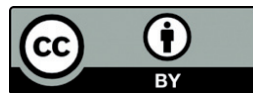

